\title{
Considering Student Writing from the Perspective of Parents in One Rural Elementary School
}

\author{
Kathy Brashears \\ Tennessee Technological University
}

This article explores the perspective of parents regarding their elementary children's writing in one rural, elementary school. During the research, thematic strands emerged indicating that parents may value their children's writing for purposes that differ from the purposes deemed appropriate by the school. Upon interviewing 30 parents/guardians, the following codes materialized identifying elements that contribute to the parents' perspectives. These elements include the following: Parents do not see the connection between school and real world writing, parents lack understanding on writing purposes, parents' perceptions of writing are based on their own school experiences, and some parents are illiterate. Not only are these elements identified, but suggestions as to how to address each are considered.

\section{Teachers Link Students’ Lack of Writing Success with a Lack of Parental Concern}

Having taught for over a decade and served as a school administrator for four years in Appalachia, I was familiar with the schoolhouse mantra that student lack of success is due to the disinterest on the part of many parents regarding their children's education. Perhaps I should not have been surprised when in the role of teaching assistant in a doctoral program, my first group of pre-service teachers voiced the same reason for many students' lack of success in writing. Intrigued, I wondered aloud how a group of pre-service teachers, with no teaching experience, had come to this conclusion. They explained that everyone knew this: It was just a fact of life.

When researching writing strategies in a rural, Appalachian school, I once again was confronted with teachers who saw a clear link to students' lack of success, particularly their inability to write well, and parents who did not care. Fueled by a need to better understand the perspective of the parent in this situation and to determine whether or not unsuccessful student writers are merely just products of uninterested or uncaring parents, I began a formal study. I hoped that by interviewing parents, particularly parents of students in Appalachia, and illuminating their thoughts on how they perceive writing, I would acquire insight that would help teachers better understand and communicate with parents regarding student writing.

\section{Background}

The literature is replete with calls for parental involvement in the classroom and, specifically, in children's learning. $\mathrm{Au}$, Carrol and Scheu (1997), for example, suggest that conversations with students' parents are an insightful way for teachers to better understand students and their backgrounds. Nistler and Maiers (2000), too, concur and refer to parents as a "powerful, underused source of knowledge” (p. 679) while Warren and Young (2002) describe parental involvement as "imperative" to student learning (p. 217). Researchers also suggest that involving parents in the learning process of their children benefits both teachers and students in developing an awareness of cultural backgrounds and differences (Nistler \& Maiers, 2000; Stotsky, 1999).

Despite these numerous calls in current literature for parental involvement, few researchers, with the exception of Heath (1983) and Purcell-Gates (1995), have explored the literacy of Appalachian children in relation to their parents (Perry, Nordby \& VandeKamp, 2003). As a result of the little emphasis in the literature on involving or informing parents about their children's writing development, teachers have not thought to share writing information with their students' families (Perry, et al. 2003). A second reason that teachers may not include parents in their children's writing development is that some teachers have observed parents scolding students regarding their writing (Perry et al., 2003). While the answer seems to be that parents need training or information to alleviate this type of concern, some teachers feel that the time it would take to train parents is prohibitive. Literature suggests yet another reason for teachers' not involving parents within their children's writing development: Teachers perceive parents as being indifferent to educational issues (Routman, 2000; Stotsky, 1999). Thus, as changes in writing expectations have occurred in state and national standards, parents remain uninformed and unaware.

Although the literature suggests these varied reasons for teachers not including parents within their children's writing development, the literature also suggests, as previously mentioned, that including parents in the educational program is beneficial to teachers and students. It seems, therefore, that knowing how parents perceive their children's writing may be beneficial in understanding whether or not factors, other than an uncaring or uninterested nature, are at play. Knowing these factors and understanding parent perspectives toward their children's 
writing development would help teachers in making plans to include parents within their children's writing program. For these reasons as well as the fact that few research studies have focused on the writing of children in Appalachia, I chose to study the perspectives of parents in Appalachia toward their children's writing in one rural, elementary school.

\section{Methodology: Site, Participants, and Data Collection}

In conducting a large research project regarding writing strategies, I located a rural, Appalachian elementary school with 466 students in kindergarten through fifth grade and, while having approximately a 50\% free and reduced lunch rate, also had at least average rankings on state tests. Because of the warm reception of the superintendent, principal, and teachers, all of whom expressed interest in my research regarding writing strategies, I extended my qualitative study to include the perceptions of parents' about their children's writing development and then sent out a letter to the parents of each student in the school. In this letter I explained that I wanted to talk with them regarding their children's writing skills. While realizing that a limitation of my study could be that only parents active in their children's school lives might volunteer, I asked teachers to recommend parents. I also included my home phone number on the letter and went to school early on a regular basis so that parents who dropped off their children and did not participate in school activities might be more likely to talk with me. As a result of persistence, I informally interviewed a total of 30 parents/guardians. These interviews took place in the teachers' workroom, school hallways, and empty classrooms and occurred during the same timeframe that I also interviewed 25 teachers and 214 students about writing practices.

\section{Findings: A Question of Perspective}

\section{Parents Value Their Children's Writing}

In the 30 interviews I conducted, no parent said that their child's writing was unimportant, but, in fact, just the opposite occurred. While this response in and of itself was expected, the details in the responses were enlightening. One parent shared that she felt "mommy guilt" if she discarded any of her child's writings or work in general. Other parents, too, indicated that they wanted to keep their children's writing, but only if it was neat and free of errors.

The care that parents show in keeping their children's papers may be indicative of the value that they place on their children's writing or work in general. One parent said that she built a "small shed" to store all her children's school papers. Both parents and students talked about special places in which they keep school papers including, plastic boxes under beds, a box that looks like a treasure chest, a silk covered box, a chest of drawers, Tupperware containers, special folders, and on refrigerators. Based on this information, parents may need opportunities presented on how to value their students' writing for purposes other than those involving handwriting and writing mechanics.

As I continued to interview parents it became clear that their perspective on their children's writing might indeed be more complex than disinterested parents. Four possibilities, other than a lack of parental concern, surfaced during my analysis of the data: Parents do not see a connection between school and real world writing, they lack understanding of writing purposes, their perceptions of writing may be skewed due to their own school experiences with writing, and some parents may be illiterate.

\section{Parents Do Not See the Connection between School and Real World Writing}

Most of the parents interviewed did not state or indicate a connection between school writing and real world writing. In fact, as stated previously, some parents seem mainly to associate writing with writing mechanics. One mother, for example, explained that her daughter, a second grader, would be a good writer if she would complete her sentences and use correct forms of punctuation and capitalization. Another mother described one of her sons as a "good writer" because he has "great penmanship" and referred to her other son as "not as good" a writer since his handwriting is "sloppy." A parent, who said her son in first grade refuses to talk about writing because he dislikes it so much, explained that he is not a good writer because he does not leave a space between words and does not pay attention to the lines on the paper when he writes. A mother of a third grader, too, said that her child does not care for writing because he "hates" to practice cursive writing. Still another parent commented on her association of writing with mechanics. She explained that one of her children spells well, due to Saxon Phonics, and, therefore, is a better writer than his sibling. She elaborated that she believes that children who are good spellers are better writers because they are "more comfortable writing words on their own," know "how to sound out words better," and know "how to break words apart better."

In the following quote from an interview, a primary teacher confirmed that her students' parents only see a purpose for writing if words are correctly capitalized or the writing neatly executed.

I think sometimes that parents have a difficult time when we do writing journals because I'm looking more for the creative part of it, what they can come up with. And parents look at it and say, 'This is messy.' You know, there's no capital letters. There's no periods (Brashears, 2004).

Another teacher lamented that her students' parents only seem to value the handwriting aspect of writing: 
I'm not sure that they [parents] understand as much as what we're doing in the classroom. I think writing and handwriting are something that parents do not understand...[W]hen I say their writing needs improvement, [their parents say] 'Oh, I know his writing isn't very neat.' You know, I'm not talking about handwriting, penmanship, and I think that's one of the things that parents do not really understand is that writing is totally different than handwriting.... (Brashears, 2004).

If parents consider writing mechanics to be the main stay of writing, it is unsurprising that their children may view writing as a school activity and not see the connection between school writing and real world writing. It, too, would appear that even if these parents worked with their children on skills that they determine are writing skills, they may not practice the skills that state standards, and therefore teachers, suggest are important. Acknowledging that parents do not value the same aspects of writing as schools, teachers may misinterpret parents' response to their children's writing as indifference rather than the result of a lack of understanding about current writing standards. As previously suggested, the lack of communication about the curricular changes in writing instruction is problematic.

\section{Parents Lack Understanding of Writing Purposes}

To better understand what types of writing parents might see as important, I asked about specific purposes for which they write and their children write. While some parents shared that they wrote grocery lists, letters to family members, e-mails, bills, notes, camping lists, homework assignments, diary entries, and words to songs, other parents shared few reasons to write. One mother, for example, when asked about the purposes for which her child needed to know how to write, shook her head from side to side and replied, "I don't really know." Another parent when asked what kind of writing your child sees you do replied, "Oh, Lord. I don't know." Other parents in response to the same question said, "I don't write a whole lot" and "I don't write no more that I have to.” As stated previously, this evidence, too, suggests that not only do parents not have a clear understanding of writing purposes, but that they do not see the connection between real life writing and school writing. In part, such an occurrence may be attributed to the lack of emphasis teachers have placed on sharing information regarding the writing process or writing in general.

\section{Parents' Perceptions of Writing is Based on Their Own School Experience}

Besides not seeing a connection between school writing and real life writing, a third reason may account for why teachers view parents as uncaring or indifferent toward their children's writing. This reason is simply that many parents may base their understanding of their children's writing on their own school experiences. In other words, when parents were in elementary school the focus on writing may have been on grammar and handwriting lessons, not creative writing or writing for different purposes as defined by state standards. In fact, when asked about their own personal writing experiences in school, most parents shared that they remembered doing very little writing in school. Those parents who did recall writing referred to handwriting lessons or writing sentences from grammar textbooks. A mother, for example, said that she remembered doing handwriting lessons, but "not other kinds of writing." A third grade teacher concurred:

And they [parents] probably see the writing, you know, I didn't do that when I was in school. We didn't have to worry about all that writing...(Brashears, field notes, 2004).

Another teacher, too, talked about how it is difficult for her students' parents to understand why emphasis is now being placed on writing:

I'm constantly hearing, 'We didn't do that in first grade... Trying to explain to them that the expectations are different [is challenging]. Sometimes they say, "Well, o.k., but I wasn't expected to do all this" so. Some parents really do value it [writing], but probably a lot of them don't see the worth of it (Brashears, 2004).

Again, teachers, not aware or open to other perspectives on writing, may misunderstand the attitudes of their students' parents. Instead of being uncaring in regards to their children's writing, parents, they may base their responses on their on school writing experiences and simply not understand writing as it is taught today. Sharing information with parents, therefore, provides the basic foundation for parents' understanding of current instructional practices in writing.

\section{Parents' Illiteracy}

Besides basing their children's writing experiences on their own school experiences, a fourth reason may account for parents not providing reasons for which their children need to write or not giving purposes for practicing their own writing skills. In other words, some parents do not engage in real world writing because they never learned how to write or have limited writing skills. A mother acknowledged this reason: She worried that her son had few family members to serve as school role models since none of them had completed their high school education. While the family resource director acknowledged that illiteracy in the community is a problem that she frequently encounters, no research has been conducted in the community surrounding the school to determine the severity of the problem. During an interview, however, she shared some of 
her experiences in working with an illiterate mother of one of her students.

I have gone on numerous occasions to get paperwork filled out by her...I try not to insult her, and I say stuff like, "Would you just like me to read this and... fill it out while you give me the answers? Then I'll just let her watch as I do it and tell her what I'm writing. It's a touchy situation because she doesn't know that I know that she can't read or write. She can sign her name and that's about it (Brashears, 2004).

Informal interviews with students in both primary and upper grades verified the information that some parents may be illiterate. Students, for example, mentioned that they personally have family members who can neither read nor write. One student, volunteered, “My step-daddy don't write," and another first grader said, "My dad doesn't write." A fifth grader, declared, "My trailer park owner don't write. He just gets other people to write for him.” A fourth grader commented, "You don't have to be able to write. You just have to have good characteristics to get through life.” One student, a fourth grader, too, commented that one member of his family, the only one with a high school degree, could not write.

As a result of parents or caregivers not modeling real world writing, children may have limited experiences seeing adults write and, therefore, fail to see a connection between school writing and real world writing (Schickedanze, 1996). While the ramifications of illiterate parents are severe, illiteracy and not an uncaring attitude may be to blame for the behaviors of parents who teachers deem uninterested in their children's work.

\section{Conclusions and Implications}

The findings of this study indicate parents' attitudes toward writing may be indicative of something other than an uncaring attitude. Instead, the perceived attitudes of parents' toward writing may indicate a lack of understanding about writing purposes, unpleasant school writing experiences, and illiteracy. Coupled with research suggesting that parental involvement is important, this study is enlightening. It provides a basis for teachers to view parents' attitudes from a different perspective and suggests five ways to better address involving parents within their children's writing program.

First, because the evidence suggests that parents do value their students' work, teachers need to take advantage of this finding and display their students' stories, poems, brochures, and other writing pieces at the bank, grocery stores, library, gas station, local library, and in the newspaper. As a result, teachers will set the stage for interest among parents and community members and encourage conversation about writing.
Second, because evidence suggests that some parents and students do not see a connection between school writing and real world writing, teachers need to consider ways in which to highlight this connection. One way is to ask community members, police personnel and firefighters, who regularly visit the school, to mention in their "talks" how they use writing in their lines of work or, otherwise, engage in real world writing. Other community workers, family business operators, the postmaster, gas station attendants, and beauticians could also speak to students about how they use writing in their chosen occupations. Parents, too, could be invited to informally talk to students about how they use writing in their everyday lives. The school could initially solicit parents for the purpose of these talks by contacting the parents who volunteer on a regular basis throughout the school. By showing parents that they value what they do and that their experience with writing in the real world is important enough to share with students, teachers are making headway into convincing not only parents, but students, that a connection between real world writing and school writing not only exists, but is strongly represented within the community.

Third, to help parents better understand the purpose of writing in the classroom, teachers and the students could invite parents into their classrooms to share with them the types of writing in which they engage. In various classrooms, students could share writing portfolios in which they display writing pieces in a variety of stages. Teachers and students, too, could share the writing process and demonstrate how they participate in pre-writing stages like brainstorming and writing a rough draft before revising, editing, and completing a finished draft. They, also, could talk about the different genres in which they write and the purposes in math, science, social studies and other curricular areas in which the write.

Fourth, in parent-teacher meetings and in other school wide meetings, teachers could stress how writing is taught and what constitutes good writing may have changed over time. Teachers could lead discussions in which they encourage parents to share their experiences with writing and facilitate open discussions of current writing standards. Teachers, along with students, could provide parents with opportunities to engage in the writing experience, alongside their children. Gallery walks, too, could be hosted in school hallways where parents, along with their children, could view students' writings at each grade level.

Fifth, in recognition that some parents may be illiterate rather than disinterested in their children's writing and schoolwork, teachers could activate a phone chain where one parents calls the next, use audio and videotapes to communicate information, and make phone calls to deliver information about writing rather than only communicate through written means. Also, in this study, since parents seemed more likely to keep students' work if it was not "canned", it may imply that if they see communication as "canned”, they are less likely to respond. More 
personalized notes, therefore, may be the answer. Although more time consuming, photocopies of handwritten notes may be more response provoking than form letters.

While all of these suggestions are specific to this study of a rural school in Appalachia, perhaps this information can at least serve as a reminder that reasons, other than an uncaring attitude, may account for parents' lack of involvement in their child's writing development. While some parents, unfortunately, may be uncaring and disinterested in their children's writing, this study indicates that other factors need to be considered. This revelation is important since if teachers accept that their students do not write well because of a lack of parental concern, teachers ultimately give themselves permission to give up on their students. As teachers, we must acknowledge that such an attitude is unacceptable and that, for some of us, teaching others to write and read is not just our responsibility, but our life's work.

\section{References}

Au, K., Carroll, J. \& Scheu, J. (1997). Balanced literacy instruction. Norwood, MA: Gordon Publishers, Inc. Brashears, K. (2004). Field notes.

Heath, S. B. (1983). Ways with words. New York: Cambridge University Press.
Nistler, R. \& Maiers, A. (2000, May). Stopping the silence: Hearing parents' voices in urban first-grade family literacy program. The Reading Teacher, 53, 670-680.

Perry, N., Nordby, C. \& VandeKamp, K. (2003). Promoting self-regulated reading and writing at home and school. The Elementary School Journal, 103, 317-337.

Purcell-Gates, V. (1995). Other people's words: The cycle of low literacy. Cambridge, MA: Harvard University Press.

Routman, R. (2000). Conversations: Strategies for teaching, learning, and evaluating. Portsmouth, $\mathrm{NH}$ : Heinemann.

Schickedanze, J. (1996). More than the ABCs: The early stages of reading and writing. Washington, D.C.: National Association for the Education of Young Children.

Stotsky, S. (1999). Losing our language: How multiculturalism undermines our children's ability to read, write, and reason. San Francisco, CA: Encounter Books.

Warren, E. \& Young, J. (2002). Parent and school partnerships. Asia-Pacific Journal of Teacher Education, 30, 217-228. 